\title{
Antibiotic suceptibility of Escherichia coli isolated in cases of urinary tract infection in Nsukka, Nigeria
}

\author{
Joan U Okafor ${ }^{1, B, C, D, F \oplus}$, Emeka I Nweze ${ }^{1, A, C, E, F} \oplus$ \\ ${ }^{1}$ University of Nigeria, Nsukka, Nigeria \\ A - Research concept and design, B - Collection and/or assembly of data, C - Data analysis and interpretation, \\ $D$ - Writing the article, E-Critical revision of the article, F- Final approval of article
}

Okafor JU, Nweze El. Antibiotic suceptibility of Escherichia coli isolated in cases of urinary tract infection in Nsukka, Nigeria. J Pre-Clin Clin Res. 2020; 14(1): 1-7. doi: 10.26444/jpccr/118949

\begin{abstract}
Introduction and objective. The study was carried out to determine the occurrence and antibiotics susceptibility profile of Escherichia coli recovered from patients with urinary tract infection (UTI) in Nsukka, southeastern Nigeria.

Materials and method. Midstream urine samples were obtained from 266 outpatients. Standardized questionnaires were used to collect relevant information from the subjects. Urine samples were plated on MacConkey and eosin methylene blue agar. E. coli isolates were identified using standardized procedure. Kirby-Bauer disc diffusion method was used to determine the susceptibility of the isolates.

Results. An overall UTI prevalence of $18.8 \%$ with 29 (19.30\%) from females and 21 (18.10\%) from males was observed. Females and males within the age range of $20-29$ and $50-59$ had the highest prevalence rate of $23.2 \%$ and $15 \%$, respectively. The highest prevalence rate (26\%) occurred in the Igbo-Etiti local government area, compared to the other four local government areas within the study locations. Urinalysis showed that 16 urine samples contained protein, 29 were nitrite positive and 31 were acidic. Most of the isolates were susceptible to nitrofurantoin (94\%), ciprofloxacin (70\%) and ofloxacin (78\%) while all of them were completely resistant to cefuroxime, ceftazidime and augmentin (100\%). All 50 (100\%)E. coli isolates showed multiple resistance to three or more antibiotics with a resistance index ranging from $0.375-1.00$. The MIC results showed that $17(34 \%)$ isolates were sensitive to gentamicin (MIC $\leq 0.25 \mu \mathrm{g} / \mathrm{ml}, \mathrm{MBC} \geq 128 \mu \mathrm{g} / \mathrm{ml}$ ), resistant to ciprofloxacin and ofloxacin. Conclusion. E. coli is predominantly associated with UTI in the study area and was susceptible to nitrofurantoin.
\end{abstract}

Key words

Escherichia coli, urinary tract infection, Nsukka, antibiotics, southeastern Nigeria

\section{INTRODUCTION}

Every year, over 150 million cases of urinary tract infections are reported [1]. This is estimated to cost the world economy over six billion US dollars [2]. The increasing resistance to bacteria etiological agents of UTI, especially in developing countries, has become a huge public health issue and a major obstacle in resolving the problem posed by UTIs. Monitoring bacteria etiological agents of UTI worldwide, as well as their resistance patterns to antibiotics, is important since the world has become a global village. Area-specific studies are useful in this regard because it can shed ight about the type of pathogens responsible for UTI in different regions, and their patterns of antibiotic sensitivity/resistance.

Escherichia coli is the major etiological agent of UTI [3, 4] and responsible for up to $90 \%$ of all UTI cases reported so far [5]. In most cases, E. coli is harmless and forms a part of the normal flora of the gut and thus disrupts the establishment of pathogenic bacteria within the intestine. UTI has been reported to be more prevalent in females than in males, especially during youth and adulthood, due to the proximity of the female urethral opening to the anus, thus enabling easier access of $E$. coli to the bladder [6]. The urinary tract comprises the lower and upper urinary tracts, and the

Address for correspondence: Emeka I Nweze, Department of Microbiology, University of Nigeria, Nsukka, Nigeria

E-mail: emeka.nweze@unn.edu.ng

Received: 14.01.2020; accepted: 13.03.2020; first published: 31.03.2020 infection is named after the part that is infected. UTI can also be symptomatic or asymptomatic [7]. UTI can cause inflammatory diseases as a result of the multiplication of the pathogen at the opening of the urinary tract, and this in turn alters the normal functioning of the urinary tract and kidneys [7].

The introduction of antimicrobial therapy has led to improvement in the management of UTI [8]. However, the emergence of antibiotic resistance by a growing number of antibiotic resistant pathogens in the management of UTI has become a serious public health problem, particularly in developing countries like Nigeria where factors such as a high poverty level, ignorance, and poor hygiene practices contributes to the incidence of UTI, as well as a high prevalence of fake and spurious drugs of questionable quality in circulation [9]. Due to the lack of a rational antibiotic policy in clinical medicine, antibiotics are misused more frequently in many developing countries which results in the emergence of many multidrug resistant (MDR) strains of pathogenic bacteria, especially Escherichia coli [10]. Hence, there is the need for a sound knowledge of the antibiotic resistance patterns of these pathogens, especially Escherichia coli, in order to ensure efficient treatment and eradication, as well as the monitoring of the epidemiology of UTI. Moreover, a better knowledge of the virulence characteristics of the main pathogen causing urinary tract infection in developing countries, such as Nigeria, will be useful in monitoring the evolution of infection in the host organism. 


\section{OBJECTIVE}

The aim of this study was to determine the prevalence and antibiotic susceptibility of E. coli recovered from urinary tract infections in the Nsukka geopolitical zone in southeastern Nigeria.

\section{MATERIALS AND METHOD}

Sample collection. Urine samples were collected from 266 patients of different age groups in the outpatient's department of each selected hospital in the six local government areas in the Nsukka geopolitical zone. All participants provided written consent after thorough explanation of the rationale for the study. Fresh voided mid-stream urine specimens $(10 \mathrm{ml})$ were obtained from patients into sterile universal screw-capped bottles. Participants were instructed on how to collect the urine samples. Each participant was given a standardized questionnaire on socio-economic status, residence, occupation, age, gender, antibiotics prophylaxis, previous UTI, and presenting symptoms. The specimens were labeled and transporte immediately in iced bags to the microbiology laboratory of the University of Nigeria in Nsukka for analyses.

Urinalysis. The urine samples were checked for colour and turbidity. Quantitative urine analysis was performed using a commercially available urine dipstick Combi 9 (ComburTestH, Roche Diagnostics, Mannheim, Germany) following the manufacturer's recommendations. The $\mathrm{pH}$, presence of glucose, protein, ascorbic acid, blood, ketone, bilirubin, urobilinogen and nitrite were noted for each sample.

Microscopy. Ten millimeters of well-mixed urine sample was centrifuged at 5,000rpm for five minutes. The supernatant was discarded, and a drop of each urine sample was placed on a glass slide and viewed at high magnificationthrough 10x and 40x objective lenses for pus cells, red blood cells, epithelial cells, casts, crystals and yeast-like cells. Pus cells $\geq 5$ per high power field was considered significant to indicate urinary tract infection. Samples with ten white blood cells / $\mathrm{mm}^{3}$ were regarded as pyuric.

Isolation and identification of $\boldsymbol{E}$. coli isolates. Using a calibrated wire loop, a loopful $(0.01 \mathrm{ml})$ of each urine sample was inoculated on MacConkey agar and incubated for 18-24 hours at $37^{\circ} \mathrm{C}$. Discrete colonies were further subcultured onto eosin methylene blue agar (Oxoid, Hampshire, United Kingdom) for isolation of the Escherichia coli present in the urine. Suggestive colonies of Escherichia coli were further inoculated on chromogenic agar for further identification. The E. coli isolates were identified on the basis of their standard cultural, morphological and biochemical characteristics, as previously described [1]. A count of $\geq 10^{5} \mathrm{CFU} / \mathrm{ml}$ was considered positive for UTI [11].

Antibiotics susceptibility test. The test was carried out using the Kirby-Bauer's method/disc diffusion method [12]. The diameters of the zones of inhibition were measured, recorded and interpreted according to Clinical and Laboratory Standards Institute approved standard guidelines [13]. Discs containing the following prepared antibacterial agents against Escherichia coli were placed onto the agar surface, cefixime $(5 \mu \mathrm{g})$, nitrofurantoin $(300 \mu \mathrm{g})$, ciprofloxacin $(5 \mu \mathrm{g})$, ceftazidime $(30 \mu \mathrm{g})$, augmentin $(30 \mu \mathrm{g})$, gentamicin $(10 \mu \mathrm{g})$, cefuroxime $(30 \mu \mathrm{g})$ and ofloxacin $(5 \mu \mathrm{g})$.

Minimum inhibitory and bactericidal concentration (MIC and $\mathrm{MBC}$ ). The broth dilution method was used to determine the MIC of three antibiotic, namely ciprofloxacin, ofloxacin and gentamicin against E. coli. E. coli was inoculated into Mueller-Hinton broth containing a two-fold serial dilution of an initial antibiotics solution of $256 \mu \mathrm{g} / \mathrm{ml}$. An uninoculated tube was used as the control. The setup was incubated for 18 hours at $37^{\circ} \mathrm{C}$. Antibiotic concentration ranged from $0.06-$ $128 \mu \mathrm{g} / \mathrm{ml}$ for ofloxacin, $0.008-128 \mu \mathrm{g} / \mathrm{ml}$ for ciprofloxacin and $0.03-128 \mu \mathrm{g} / \mathrm{ml}$ for gentamicin. The minimum bactericidal concentration (MBC) was determined by subculturing on antibiotics-free Mueller Hinton agar plates, $0.01 \mathrm{ml}$ of the broth culture of the organism/antibiotic's mixture (at MIC) that showed no visible growth. The lowest concentration that showed no growth on the antibiotics-free medium after overnight incubation (18-24) hours was recorded as the MBC.

Multiple antibiotics resistance (MAR) indexing. Multiple antibiotics resistance index (MAR) was calculated for each $E$. coli isolate recovered, after subjecting them to a panel of eight antibiotics. The formula used was $\mathrm{x} / \mathrm{y}$ where ' $\mathrm{x}$ ' represents the number of antibiotics to which the isolate is resistant, and $y$ represents the total number of antibiotics to which the isolate was exposed [14]. The E. coli isolates resistant to three or more antibiotics were classified as multiple antibiotics resistant (MAR) isolates, while those resistant to less than three antibiotics were classified as non-multi-antibiotic resistant (NMAR) isolates.

\section{RESULTS}

In the study, the overall prevalence rate of UTI was $18.8 \%$ with 50 ( 29 females and 21 males) of the 266 patients positive for UTI. Females within the age range 20-29 years had the highest prevalence rate $(23.0 \%)$, followed by those in the age range $30-39$ years $(22.7 \%), 10-19$ years $(20.0 \%)$, while those within the age range $50-59$ years $(2.5 \%)$ had the least prevalence. Among the males, the highest prevalence was also observed in the age range $50-59$ years (15\%), followed by those above 70 years (13.0\%) and $60-69$ years $(10.7 \%)$, while the least was found in the age range $20-29$ years (3.6\%). Within the study areasthe Igbo-Etiti local government area was observed to have the highest prevalence rate $(26.0 \%)$, followed by Igbo- Eze North (24.0\%), Nsukka (18.0\%), IgboEze South 16\%, and Uzo-Uwani (9.5\%), while the Udenu local government area had the lowest rate (6.0\%).

Participants in the rural communities showed the highest prevalence rate (84\%) while those in the urban community had a low prevalence (16\%). Participants who were single at the time of the study had the highest prevalence (64\%), followed by those who were married (32\%), while the widows/ widowers had the least prevalence (4\%). With respect to occupation, students showed the highest prevalence (58\%), while farmers had the least prevalence (4\%). In the same vein, participants with tertiary level of education had the highest prevalence (58\%), while those with no formal education had the least prevalence (4\%). Among the positive samples, 58\% 
presented symptoms of UTI at the time of study, while $42 \%$ were without symptoms.

Urine analysis showed that of 50 of positive urine samples, 29 were positive for nitrite, 16 were protein positive, 14 had ascorbic acid, and two urine samples had a small glucose concentration. The urinalysis also showed high acidity in 31 urine samples (11 males and 20 females) and a turbid appearance of urine samples was observed in 31 urine samples. Microscopy of centrifuged urine samples showed a high number of calcium oxalate crystals in five urine samples (two males and three females), sulfonamide crystals in two female urine samples while cysteine crystal and triple phosphate crystal were found in two urine samples (a male and a female). Fourteen (14) urine samples (two males and 12 females) had numerous epithelial cells, and red blood cells were found in two female urine samples. There were a significant number of pus cells (pyuria) in 32 urine samples (15 males and 17females). Hyaline casts were also found in five urine samples (two males and three females) while granular cast was found in a male urine sample.

Among the antibiotics tested in the study, the highest rate of resistance of $E$. coli was found for cefuroxime (100\%), ceftazidime (100\%), augmentin (100\%) and cefixime (74\%), while the sensitivity patterns of E. coli to the antibiotics tested were highest in nitrofurantoin (94\%), ofloxacin (78\%), ciprofloxacin (70\%) and gentamicin (66\%). E. coli recovered from females had the highest sensitivity rate to nitrofurantoin (56\%), ofloxacin (48\%) and ciprofloxacin (46\%) while males had sensitivity rate of nitrofurantoin $(38 \%)$, ofloxacin (30\%) and gentamicin (28\%). E. coli recovered from the various study areas were observed to have almost the same sensitivity rate to nitrofurantoin, ofloxacin, gentamicin, ciprofloxacinand gentamicin. All isolates from the study areas (local government areas) were $100 \%$ resistant to cefuroxime, ceftazidime and augmentin.

All the Escherichia coli isolates recovered exhibited an overall multiple antibiotic resistance (MAR) index range of $0.375-$ o 1.0. A total of fifty $E$. coli isolates were subjected to MIC determination, of which 38 (76\%) of the isolates were resistant to ciprofloxacin, while $24 \%$ were sensitive. Also, 37 (74\%) were resistant to ofloxacin while $13(6 \%)$ were sensitive. Lastly, $33(66 \%)$ of the isolates were resistant to gentamicin and $17(34 \%)$ were sensitive to it. $\mathrm{MIC}_{50}$ was found to be between $32 \mu \mathrm{g} / \mathrm{ml}$ and $64 \mu \mathrm{g} / \mathrm{ml}$, while MIC $_{90}$ was observed to be at $128 \mu \mathrm{g} / \mathrm{ml}$ for the antibiotics tested.

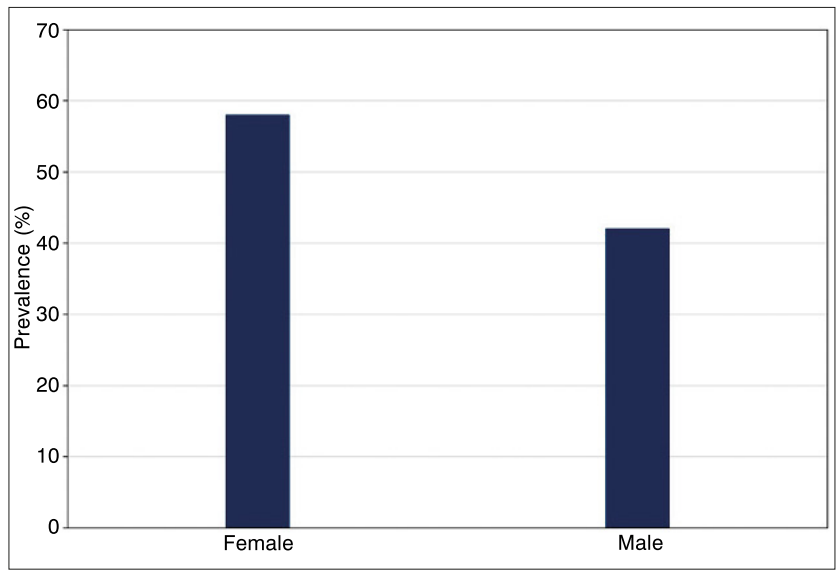

Figure 1. Gender distribution of UTI
Table 1. Age and gender distribution of UTI

\begin{tabular}{lccc}
\hline Age groups & Number tested & $\begin{array}{c}\text { Number positive (\%) } \\
\text { Male Female }\end{array}$ & Total prevalence (\%) \\
\hline $0-9$ & 17 & $0(0.0) 2(11.8)$ & $2(11.8)$ \\
\hline $10-19$ & 5 & $0(0.0) 1(20.0)$ & $1(20.0)$ \\
\hline $20-29$ & 56 & $2(3.6) 13(23.2)$ & $15(26.8)$ \\
\hline $30-39$ & 22 & $0(0.0) 5(22.7)$ & $5(22.7)$ \\
\hline $40-49$ & 41 & $3(7.3) 3(7.3)$ & $6(14.6)$ \\
\hline $50-59$ & 40 & $6(15.0) 1(2.5)$ & $7(17.5)$ \\
\hline $60-69$ & 28 & $3(10.7) 1(3.6)$ & $4(14.3)$ \\
\hline$\geq 70$ & 57 & $7(12.2) 3(5.3)$ & $10(17.5)$ \\
\hline Total & $\mathbf{2 6 6}$ & $\mathbf{2 1 ( 4 2 . 0 ) ~ 2 9 ( 5 8 . 0 )}$ & $\mathbf{5 0 ( 1 8 . 8 )}$
\end{tabular}

Table 2. Socio-demographic characteristics of the study participants

\begin{tabular}{lcc}
\hline Status & $\begin{array}{c}\text { Total number } \\
\text { Sampled (\%) }\end{array}$ & $\begin{array}{c}\text { UTI positive } \\
\text { Samples (\%) }\end{array}$ \\
\hline Locality & $216(81)$ & $42(84)$ \\
Rural & $50(19)$ & $8(16)$ \\
Urban & & \\
\hline Marital status & $112(42)$ & $32(64)$ \\
Single & $136(51)$ & $16(32)$ \\
Married & $3(1)$ & $0(0)$ \\
Divorced & $15(6)$ & $2(4)$ \\
Widow/Widower & & $29(58)$ \\
\hline Occupation & $67(25)$ & $8(16)$ \\
Students & $88(33)$ & $7(14)$ \\
Civil servants & $56(21)$ & $2(4)$ \\
Traders & $19(7)$ & $4(8)$ \\
Farmers & $29(11)$ & $0(0)$ \\
Unemployed & $7(3)$ & $12(24)$ \\
Others* & & $7(14)$ \\
\hline Literacy level & $87(33)$ & $29(58)$ \\
Basic/Primary* & $67(25)$ & $29(4)$ \\
Secondary* & $55(21)$ & \\
Tertiary* & $57(21)$ & \\
None & $125(47)$ & \\
\hline Symptoms of UTI & $141(53)$ & \\
Yes & & \\
No & & \\
\hline & & \\
$*$ & & \\
\hline
\end{tabular}

*Others - includes artisans; Basic/Primary - school for children aged between about five and eleven where they receive elementary education; Secondary - school for children aged between 11-18 where they receive secondary education, e.g. technical and vocational courses; Tertiary - post-secondary education which focuses on learning endeavors in specialized fields, including academic and higher vocational education.

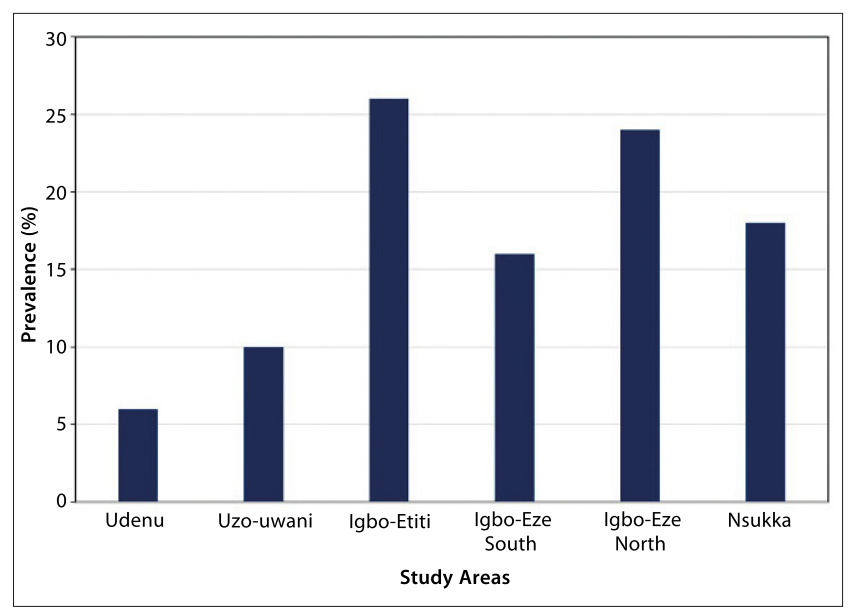

Figure 2. Prevalence of UTI in different local government areas in Nsukka geopolitical zone 


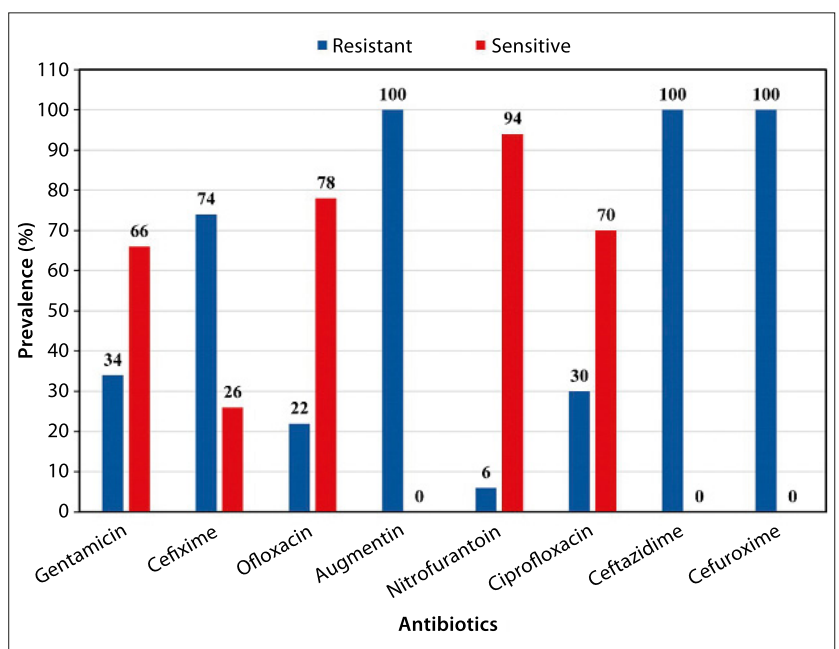

Figure 3. Sensitivity and resistance profiles (\%) of E. coli to eight antibiotics

Table 3. Sensitivity (S) and resistance (R) patterns (\%) of E. coli isolates recovered fromdifferent local government areas in Nsukka geopolitical zone

\begin{tabular}{|c|c|c|c|c|c|c|c|c|c|c|c|c|}
\hline \multirow[t]{2}{*}{$\begin{array}{l}\text { Antibiotics } \\
\text { tested }\end{array}$} & \multicolumn{2}{|c|}{$\begin{array}{l}\text { Igbo- } \\
\text { EzeSouth }\end{array}$} & \multicolumn{2}{|c|}{$\begin{array}{l}\text { Igbo- } \\
\text { EzeNorth }\end{array}$} & \multicolumn{2}{|c|}{ Nsukka } & \multicolumn{2}{|c|}{$\begin{array}{l}\text { Uzo- } \\
\text { Uwani }\end{array}$} & \multicolumn{2}{|c|}{$\begin{array}{l}\text { Igbo- } \\
\text { Etiti }\end{array}$} & \multicolumn{2}{|c|}{ Udenu } \\
\hline & $S$ & $\mathrm{R}$ & $S$ & $\mathrm{R}$ & $S$ & $\mathrm{R}$ & $S$ & $R$ & $S$ & $\mathrm{R}$ & $S$ & $\mathrm{R}$ \\
\hline entar & 63 & 37 & 80 & 20 & 67 & 33 & 80 & 20 & 54 & 46 & 33 & 67 \\
\hline floxacin & 75 & 25 & 100 & 0 & 56 & 44 & 100 & 0 & 69 & 31 & 67 & 33 \\
\hline $\begin{array}{l}\text { itro- } \\
\text { Irantoin }\end{array}$ & 87 & 13 & 100 & 0 & 100 & 0 & 100 & 0 & 85 & 15 & 100 & 0 \\
\hline $\begin{array}{l}\text { pro- } \\
\text { oxacin }\end{array}$ & 63 & 37 & 100 & 0 & 44 & 56 & 100 & 0 & 54 & 46 & 67 & 33 \\
\hline Augmentin & 0 & 100 & 0 & 100 & 0 & 100 & 0 & 100 & & 100 & 0 & 100 \\
\hline Cefixime & 37 & 63 & 40 & 60 & 33 & 67 & 40 & 60 & 15 & & 33 & 67 \\
\hline $\begin{array}{l}\text { eftazi- } \\
\text { lime }\end{array}$ & 0 & 100 & 0 & 100 & 0 & 100 & 0 & 100 & 0 & 100 & 0 & 100 \\
\hline Cefuroxime & 0 & 100 & 0 & 100 & 0 & 100 & 0 & 100 & 0 & 100 & 0 & 100 \\
\hline
\end{tabular}

Table 4. Antibiotics sensitivity and resistance patterns of $E$. coli isolates recovered from urine samples among gender groups

\begin{tabular}{|c|c|c|c|c|c|c|}
\hline Antibiotics & Male & (\%) & Female & (\%) & Total & (\%) \\
\hline Tested & $S$ & $\mathrm{R}$ & $\mathrm{S}$ & $\mathrm{R}$ & $S$ & $\mathrm{R}$ \\
\hline Gentamicin & $14(28)$ & $7(14)$ & $19(38)$ & $10(20)$ & $33(66)$ & $17(34)$ \\
\hline Cefixime & $4(8)$ & $17(34)$ & $9(18)$ & $20(40)$ & $13(26)$ & $37(74)$ \\
\hline Ofloxacin & $15(30)$ & $6(12)$ & $24(48)$ & $5(10)$ & $39(78)$ & $11(22)$ \\
\hline Augmentin & $0(0)$ & $21(42)$ & $0(0)$ & $29(58)$ & $0(0)$ & $50(100)$ \\
\hline Nitrofurantoin & $19(38)$ & $2(4)$ & $28(56)$ & $1(2)$ & $47(94)$ & $3(6)$ \\
\hline Ciprofloxacin & $12(24)$ & $9(18)$ & $23(46)$ & $6(12)$ & $35(70)$ & $15(30)$ \\
\hline Ceftazidime & $0(0)$ & $21(42)$ & $0(0)$ & $29(58)$ & $0(0)$ & $50(100)$ \\
\hline Cefuroxime & $0(0)$ & $21(42)$ & $0(0)$ & $29(58)$ & $0(0)$ & $50(100)$ \\
\hline
\end{tabular}


frequency of prostate disease and diabetes mellitus in males are responsible for the increase in the the incidence of UTI in elderly patients. This report is similar to some studies [31, $16]$ in chich a prevalence of $23.3 \%$ was reported in females aged 26-30 years, and in disagreement with another study that showed that female patients within the age range 37-47 years had the highest prevalence rate of $46.2 \%$, followed by $26-36$ years (31.1\%), 15-25 years (18.2\%) and above 48 years of age, showed the lowest prevalence of $4.5 \%$, while among the male patients, $37-47$ years showed the highest prevalence rate of $51.3 \%$, followed by $26-36$ years (29.5\%), 15-25 years (14.1\%), and above 48 years of age showed the lowest (5.1\%) [25]. Statistical analysis showed that there was no significant difference between age and gender at 5\% $(\mathrm{P}<0.05)$.

Participants in the rural communities in this study showed the highest UTI prevalence of $84 \%$ while the urban communities had a prevalence of $16 \%$. Those who were single at the time of the study had the highest prevalence of $64 \%$, followed by those who were married - $32 \%$, while widows/widowers had $4 \%$. This is similar to a previous report [25] chich reported that single individuals had the highest prevalence (44\%), followed by those who were married (27\%), divorced/separated (18\%) and widows/widowers (11\%). His is contrary to a study that reported the highest prevalence of UTIs among married women (66\%), followed by those who were single (24\%) [32]. The highest prevalence of UTIs among single individuals might be attributed to multiple sex partners and unfaithfulness to one sex partner, both of which are common within the study areas. The lower incidence rate of urinary tract infection reported among those who were married and widow/widower in this study may be attributed to adherence to single partners anda high degree of hygiene. With respect to occupation, students showed the highest prevalence(58\%), followed by civil servants (16\%), traders (14\%) and the unemployed (8\%), while farmers had the least prevalence (4\%). This is similar to a report by [25] that showed studentsas having the highest prevalence rate (42\%), followed by civil servants (30\%), small traders (15\%), and casual labourers who showed the least prevalence (13\%). This report is not in agreement with findings in [33] where amall traders showed the highest prevalence rate $(33 \%)$, followed by casual labourers (30\%), civil servants (21\%), and students showed the least (17\%).

In the same vein, participants with tertiary education had the highest prevalence (58\%), while those with no formal education had the least prevalence (4\%). The high prevalence rate of UTI observed in those who had tertiary education may be due to the lack of exposure to health education. This result colincides with reports from [33] who reported a high prevalence rate of UTI among those in high school (35\%) and higher education (tertiary) students (25\%), and in disagreement with Rother studies [34] which showed that women with little or no education and low socio-economic status had a high prevalence of UTI. A study also reported the highest prevalence of UTIs among students in high schools (35\%), followed by students in higher education (25\%), illiterates (18\%), and educated individuals who recorded the least (3\%) [35]. The highest prevalence rate of UTI among those with no formal education was observed to be $33 \%$ while those in high school was the least with a prevalence of 13\% [36]. The prevalence of UTI in this study was also observed to be high (58\%) in participants having symptoms of UTI while $42 \%$ were without symptoms as at the time of the study. This is as a result of the symptoms being good pointers to the infection.

In the current study, microscopy of the urine samples showed the presence of many pus cells (white blood cells), epithelia cells and casts in samples that were positive for UTI. The presence of epithelia cells may be due to vaginal contamination during sample collection. Different crystal types indicate the presence or absence of an infection. The presence of calcium oxalate crystals can be due to chronic dehydration or hyperparathyroidism chich, in turn, can lead to urinary tract infection due to the presence of calculi (stones) in the urinary tract. Cysteine crystals are found in cystinuria which is a rare congenital metabolic disorder. Urinalysis showed a large presence of protein, nitrite and ascorbic acid in urine samples. The presence of protein in urine (proteinuria) is usually an indication of kidney disorders, including glomerulonephritis and urinary tract infection. Nitrates are found in normal urine and are the result of consuming a diet containing vegetables which are reduced to nitrites by organisms such as E. coli and Klebsiella spp in large quantities.

The E. coli isolates recovered in the presented study showed high sensitivity to flouroquinolones, as was observed in another study [16]. E. coli isolates recovered in the current study were $94 \%$ sensitive to nitrofurantoin, $78 \%$ to ofloxacin and $70 \%$ to ciprofloxacin. The antibiotics sensitivity test result in this study shows that nitrofurantoin was the most effective antibiotic, followed by ofloxacin and ciprofloxacin. This is similar to the finding where sensitivity of E. coli to nitrofuratoin was $95.6 \%$ [37]. In other studies performed in developing countries, E. coli demonstrated a lower sensitivity to ciprofloxacin of between $15-43.2 \%$ [38]. Gentamicin was active against $66 \%$ of the $E$. coli isolates recovered. The antibacterial activity of gentamicin against the isolates in the presented study is comparable to the finding in Maiduguri, Northern Nigeria, where less than $70 \%$ of E. coli isolates were sensitive to this antibiotic [39]. The resistance of the isolates tested showed high resistance rates to cefixime (74\%), augmentin (100\%), ceftazidime (100\%) and cefuroxime (100\%), which is similar to a study in India [40].

The Escherichia coli isolates in the current study had an MAR index ranging from $0.375-1.0$, which is an indication that the E. coli isolates had been exposed to several antibiotics. All E. coli isolates (100\%) in this study were multidrug resistant to the antibiotics tested. This is similar to a study that recorded an overall prevalence of MDR of 73\% [16]. This is similar to study in southeastern Nigeria [25] and in disagreement with the current study [41]. The high prevalence of MDR in this study might be the result of difference in the definition used for multidrug resistance in this study, and the multiple resistant genes possessed by the isolates on their mobile genetic elements [42]. Self-medication, which is a common practice in the study area [2], also might have a major role in the development of such a higher prevalence of MDR [43].

The MIC results showed that $76 \%, 74 \%$ and $66 \%$ of the isolates were resistant to ciprofloxacin, ofloxacin and gentamicin, respectively, which is similar to a study reported [44]. This could be the result of the misuse and frequent exposure to fluoroquinolones, leading to an increase in the MIC of this antibiotic. Also, fluoroquinolone resistance in $E$. coli can emerge, particularly in patients with urinary tract infections, who have received fluoroquinolone prophylaxis 
[45]. Usually, the prevalence of fluoroquinolone resistance is related to the intensity of antibiotic use [45]. An association between the increase in quinolone prescriptions and an increase in bacterial resistance has been reported from several countries [46].

\section{CONCLUSION}

The overall prevalence of UTI in the Nsukka geopolitical zone was $18.8 \%$. The increasing level of antibiotic resistance, especially to the fluoroquinolones and cephalosporins, has become a major health problem globally and calls for an urgent review and implementation of effective antibiotic policy in Nsukka and its environs in southeastern Nigeria. This will assist clinicians in the rational choice of antibiotics therapy in avoiding the misuse of these antibiotics. Antibiotic analysis and good stewardship practice in antibiotics by patients in this study area will also help bring about the complete elimination of the surge of antibiotic resistance.

\section{REFERENCES}

1.Dibua UME, Onyemerela IS, Nweze EI. Frequency, urinalysis and susceptibility profile of pathogens causing urinary tract infections in Enugu State, Southeast Nigeria. Rev Inst Med Trop Sao Paulo. 2014 56(1): 55-59. https://doi.org/10.1590/S0036-46652014000100008

2. Eticha T. Prevalence and predictors of self-medication with antibiotics among Adi-haqi Campus students of Mekelle University, Ethiopia. IJPSR. 2014; 5: 678-84.

3. Hooton TM. Uncomplicated urinary tract infection. N Engl J Med. 2012; 366: 1028-1037. https://doi.org/10.1056/NEJMcp1104429

4. Martin O, Adamu AA, Julius T, Josephat NM, Eddie W, Charles DK, et al. Prevalence of Bacterial Urinary Tract Infections and Associated Factors among Patients Attending Hospitals in Bushenyi District, Uganda. Int J Microbiol. 2019; 8 pages. https://doi.org/10.1155/2019/4246780

5. Omigie O, Okoror L, Umolu P, Ikuuh G. Increasing resistance to quinolones: A four-year prospective study of urinary infection pathogens. Int J Gen Med. 2009; 2: 171-175. https://doi.org/10.2147/ ijgm.s2641

6. Kebira AN, Ochola P, Khamadi SA. Isolation and antimicrobial susceptibility testing of Escherichia coli causing urinary tract infections. J Appl Biosci. 2009; 22: 1320-1325.

7. Agarwal J, Srivastava S, Singh M. Pathogenomics of uropathogenic Escherichia coli. Indian J Med Microbiol. 2012; 30(2): 141-9. https:// doi.org/10.4103/0255-0857.96657

8. Habte TM, Dube S, Ismail N, Hoosen AA. Hospital and community isolates of uropathogens at a tertiary hospital in South Africa. S Afr Med J. 2009; 99: 584-587.

9. Abubakar EM. Antimicrobial susceptibility pattern of pathogenic bacteria causing urinary tract infections at the specialist hospital, Yola, Adamawa State, Nigeria. J Clin Med Res. 2009; 1(1): 001-008.

10. Sibanarayan R, Rabindra N, Padhy. Surveillance of acute community acquired urinary tract bacterial infections. J Acute Dis. 2015; 4(3): 186-195. https://doi.org/10.1016/j.joad.2015.06.001

11. Cheesebrough M. District laboratory practice in tropical countries. Part 2. Cambridge University Press City. 2010; p357.

12. Bauer AW, Kirby WMM, Sherris JC, Turck M. Antibiotic susceptibility testing by a standardized single disk method. Am J Clin Patho. 1966; 36: 493-496. https://doi.org/10.1093/ajcp/45.4_ts.493

13. Clinical and Laboratory Standards Institute (CLSI). Performance standards for antimicrobial susceptibility testing; twenty-third informational supplement. CLSI document M100-S23. CLSI, 950 West Valley Road, Suite 2500, Wayne, Pennsylvania 19087, USA; 2013.

14. Akinjogunla OJ, Enabulele IO. Virulence factors, plasmid profiling and curing analysis of multi-drug resistant Staphylococcus aureus and Coagulase negative Staphylococcus spp isolated from patients with acute otitis media. J Am Sci. 2010; 6(11): 1022-1033.

15. Syed SA, Ali S, Abdulaziz AA, Ibrahim HB, Badr NA. Uropathogens and their antimicrobial resistance patterns: Relationship with urinary tract infections. Int J Health Sci. 2019; 13: 48-55.
16. Gebremariam G, Legese H, Woldu Y, Araya T, Hagos K, GebreyesusWasihun A. Bacteriological profile, risk factors and antimicrobial susceptibility patterns of symptomatic urinary tract infection among students of Mekelle University, northern Ethiopia. BMC Infectious Diseases. 2019; 19: 950. https://doi.org/10.1186/s12879019-4610-2

17. Kabew G, Abebe T, Miheret A. A retrospective study on prevalence and antimicrobial susceptibility patterns of bacterial isolates from urinary tract infections in Tikur Anbessa specialized teaching hospital Addis Ababa, Ethiopia. Ethiop J Health Dev. 2013; 27(2): 111-117.

18. Ngwa YB, Iliyasu H, Young E, Owuna G. Bacteriuria and antimicrobial susceptibility of Escherichia coli isolated from urine of asymptomatic university students in Keffi, Nigeria. Jundishapur J Microbiol. 2012; 5(1): 323-7.

19. Ayoade F, Moro DD, Ebene OL. Prevalence and antimicrobial susceptibility pattern of asymptomatic urinary tract infections of bacterial and parasitic origins among university students in redemption camp, Ogun State, Nigeria. OJMM. 2013; 3: 219-26. http://dx.doi. org/10.4236/ojmm.2013.34033

20. Sharma E, Thakuriya R, Kumar HG. Study of predictors of urinary tract infections in nursing. IJRTSAT. 2015; 15(3): 442-3.

21. Nsofor CA, Obijuru CE, Ozokwor CL. Asymptomatic bacteriuria among female students of a tertiary institution in southeast Nigeria. ECBVR. 2016: 4(2): 106-112.

22. Wogu MD, Ogbebor NE. Prevalence of asymptomatic bacteriuria in secondary school students in Benin City. AFRREV. 2011; 5(4): 145-151.

23. Helen OO, Ossai OS. Asymptomatic bacteriuria among secondary school students in Benin City, Nigeria. JPHE. 2013; 5(2): 66-9.

24. Kolawole AS, Kolawole OM, Kandaki-Olukemi YT, Babatunde SK, Durowade KA, Kolawole CF. Prevalence of urinary tract infection among patients attending DalhatuAraf Specialist Hospital, Lafia, Nassarawa State, Nigeria. Int J Med Sci. 2009; 1(5): 163-167. https:// doi.org/10.5897/IJMMS

25. Alo MN, Saidu AY, Ugah UI, Alhassan M. Prevalence and antbiogram of bacterial isolates causing urinary tract infections at Federal Teaching Hospital Abakaliki I (FETHA I). BMRJ. 2015; 8(2): 403-417. https://doi. org/10.9734/BMRJ/2015/16696

26. Obiogbolu CH, Okonko IO, Anyamere CO, Adedeji AO, Akanbi AO, Ogun AA, et al. Incidence of urinary tract infections (UTIs) among pregnant women in Awka metropolis, Southeastern Nigeria. SRE. 2009; 4(8): 820-824.

27. Aiyegoro OA, Igbinosa OO, Ogunmwonyi IN, Odjadjare EE, Igbinosa $\mathrm{OE}$, Okoh AI. Incidence of urinary tract infection (UTI) among children and adolescents of Ile-Ife Nigeria. Afr J Microbiol Res. 2007; 1: 13-9.

28. Wei CT, Piotr MC. Urinary tract infections in adults. Singap Med J. 2016; 57(9): 485-90. https://dx.doi.org/10.11622\%2Fsmedj.2016153

29. Alkhyat SH, Maqtari MAA. Prevalence of microorganisms isolates from urinary tract infections at some hospitals in Sana'a City, Yemen. Int J Curr Microbiol App Sci. 2014; 3(6): 876-885.

30. Nicolle LE. Uncomplicated urinary tract infection in adults including uncomplicated pyelonephritis. Urol Clin North Am. 2008; 35(1): 1-12. https://doi.org/10.1016/j.ucl.2007.09.004

31. Arul KC, Dileesh KG, Kumar MA. Cross sectional study on the distribution of urinary tract infection and their antibiotic utilization pattern in Kerala. International Journal of Pharm Tech Research. 2012; 3 (3): 1125-1130.

32. Onoh RC, Umeora OUJ, Egwuatu VE, Ezeonu PO, Onoh TPJ. Antibiotic sensitivity pattern of uropathogens from pregnant women with urinary tract infection in Abakaliki, Nigeria. Infect Drug Resist. 2013; 6: 225233. https://doi.org/10.2147/IDR.S46002

33. Demilie T, Beyene G, Melaku S, Tsegaye D. Urinary bacterial profile and antibiotic susceptibility pattern among pregnant women in North West Ethiopia. Ethiop J Health Sci. 2012; 2(2): 121-128.

34. Oladeinde BH, Omoregie R, Olley M, Anunibe JA. Urinary tract infection in a rural community of Nigeria. N Am J Med Sci. 2011; 3(2): 75-77. https://dx.doi.org/10.4297\%2Fnajms.2011.375

35. Emiru T, Beyene G, Tsegaye W, Melaku S. Associated risk factors of urinary tract infection among pregnant women at FelegeHiwot Referral Hospital, Bahir Dar, North West Ethiopia. BMC Res Notes. 2013; 6: 292. https://doi.org/10.1186/1756-0500-6-292

36. Chukwu OS, Ezeonu IM, Agah VM, Alo MN, Ugah UI. Bacteriuria in pregnant women in Nsukka Urban, Enugu State, Nigeria. W J Life Sci Med Res. 2014; 3(3): 94-100.

37. Ganesh R, Shrestha D, Bhattachan B, Rai G. Epidemiology of urinary tract infection and antimicrobial resistance in a pediatric hospital in Nepal. BMC Infect Dis. 2019; 19: 420. https://doi.org/10.1186/s12879019-3997-0 
38. Aboderin OA, Abdu AR, Odetoyin BW, Lamikanra A. Antimicrobia resistance in Escherichia coli strains from urinary tract infections. J Natl Med Assoc. 2009; 101: 1268-1273. https://doi.org/10.1016/s00279684(15)31138-x

39. Rabasa AI, Gofama MM. Urinary tract infection in febrile children in Maiduguri North Eastern Nigeria. Niger J Clin Pract. 2009; 12: 124-7.

40. Poonam US, Ulka B. Isolation and identification of bacteria causing urinary tract infections in pregnant women in Vidarbha and their drug susceptibility patterns in them. Int J Curr Microbiol App Sci. 2013; 2(4): 97-103.

41. Olayinka BO, Olonitola OS, Olayinka AT, Agada EA. Antibiotic susceptibility pattern and multiple antibiotic resistance index of Pseudomonas aeruginosa urine isolates from a University Teaching Hospital. Afr J Clin Exper Microbiol. 2004; 5(2): 198-202. http://dx.doi. org/10.4314/ajcem.v5i2.7377

42. Gillespie SH, Bamford KB. Resistance to antibacterial agents. In Medical Microbiology and Infection at a Glance. 4th ed. UK: Wiley-Blackwell; 2012. p. 20-2.
43. Alabi OS, Onyenwe NE, Satoye KA, Adeleke OE. Prevalence of extended spectrum $\beta$-lactamase producing isolates from asymptomatic bacteriuria among students in a tertiary institution in Ibadan, Nigeria. J Nat Sci. 2014; 12(4): 111-4.

44.Jharna MN, Srinivas AD, Buddhapriya, Subhash CP. Antibiotic resistance pattern among common bacterial uropathogens with a special reference to ciprofloxacin resistant Escherichia coli. Indian J Med Res. 2012; 136:842-849.

45.Zervos MJ, Hershberger E, Nicolau DP, Ritchie DJ, Blackner LK, Coyle EA. Relationship between fluoroquinolone use and changes in susceptibility to fluoroquinolones of selected pathogens in 10 United States teaching hospitals, 1991-2000. Clin Infect Dis. 2003; 37: 1643-8. https://doi.org/10.1086/379709

46. Kahlmeter G. Prevalence and antimicrobial susceptibility of pathogens in uncomplicated cystitis in Europe. Int J Antimicrob Agents. 2003; 2: 49-52. https://doi.org/10.1016/s0924-8579(03)00229-2 